\title{
Strategi Pengembangan Kawasan Wisata Berbasis Industri Kreatif di Kota Mojokerto
}

\author{
Dini Norma Perwirasari dan Annisa Mu'awanah Sukmawati \\ Program Studi Perencanaan Wilayah dan Kota, Fakultas Sains dan Teknologi \\ Universitas Teknologi Yogyakarta \\ e-mail: diniperwira@gmail.com
}

\begin{abstract}
Abstrak-Objek wisata tidak harus berupa tempat-tempat yang memiliki keindahan alam, sarana rekreasi, nilai budaya, maupun nilai sejarah tersendiri. Namun, suatu proses produksi menghasilkan suatu barang tertentu pada sektorsektor kreatif juga berpotensi untuk dikembangkan menjadi objek daya tarik wisata (ODTW). Kota Mojokerto merupakan kota yang memiliki potensi sektor kreatif di bidang industri pengolahan, seperti industri kulit, barang dari kulit, alas kaki, dan miniatur kapal. Keterbatasan Sumber Daya Alam (SDA) Kota Mojokerto yang dapat dimanfaatkan sebagai objek wisata menjadi alasan utama untuk mendorong potensi sektor kreatif lainnya. Potensi komoditi unggulan industri kreatif pada setiap kecamatan di Kota Mojokerto menjadi peluang yang dapat dimanfaatkan sebagai pendorong sektor yang lain, yaitu sektor pariwisata. Tujuan penelitian ini adalah merumuskan strategi-strategi pengembangan kawasan wisata industri kreatif di Kota Mojokerto. Penelitian ini menggunakan metode penelitian kualitatif dengan teknik pengumpulan data primer melalui hasil observasi lapangan dan wawancara dengan para pemangku kepentingan menggunakan teknik purposive sampling. Sedangkan data sekunder didapatkan dari hasil telaah dokumen terkait. Dalam menganalisis potensi, masalah dan isu yang sedang berkembang akan menggunakan teknik analisis SWOT pendekatan kualitatif serta analisis penguatan isu strategis. Hasil dari analisis SWOT tersebut berupa matriks strategi pengembangan. Hasil penelitian menunjukkan bahwa tiap kecamatan di Kota Mojokerto memiliki ciri khas produk unggulan yang dapat dijadikan modal untuk dikembangkan dengan konsep One District One Product (ODOP). Rumusan strategi pengembangan dibagi menjadi dua, yaitu strategi spasial dan nonspasial. Elaborasi dari kedua strategi tersebut diharapkan dapat menjadi preskripsi bagi Kota Mojokerto untuk mewujudkan pembangunan yang efisien, produktif dan berkelanjutan.
\end{abstract}

Kata Kunci- industri kreatif, Kota Mojokerto, objek daya tarik wisata (ODTW), one district one product (ODOP).

\section{PENDAHULUAN}

Nbag aat ini ekosistem persaingan global kian menjadi tuntutan bagi daerah. Khususnya di kawasan perkotaan dituntut agar mampu menghasilkan output secara efisien dan produktif namun tetap berkelanjutan. Efisiensi yang didorong produktivitas dalam meningkatkan pertumbuhan ekonomi dan kesejahteraan masyarakat dapat memicu timbulnya pemikiran kreatif yang pada akhirnya dapat memunculkan sebuah ide kreatif. Kreativitas akan mendorong inovasi yang menciptakan nilai tambah di berbagai aspek. Kreativitas menjadi langkah awal terjadinya inovasi (penemuan) perubahan-perubahan yang berbeda dari sebelumnya.

Dalam aspek spasial (keruangan), manfaat hubungan kreativitas dengan aspek spasial adalah perwujudan dalam penguatan citra sebuah kawasan serta identitas budaya daerah. Bagi aspek ekonomi kontribusi kreativitas menciptakan iklim ekonomi kreatif yang dapat menjadi peluang baru untuk perekonomian masa depan.

Industri kreatif merupakan salah satu yang potensial bagi perkembangan ekonomi suatu wilayah. Industri pariwisata berkaitan dengan industri kreatif karena saling melengkapi satu dengan lainnya atau terdapat linkage antara keduanya [1]. Banyak industri kreatif yang berpotensi untuk dikemas menjadi aktivitas pariwisata maupun penunjang wisata [1]. Untuk mengintegrasikan antara industri kreatif dan industri pariwisata diperlukan kapasitas sumber daya manusia yang mumpuni agar mampu mengelola dan menciptakan inovasi dan kreativitas [1].

Keberadaan industri kreatif yang juga berpotensi menarik minat wisatawan dapat memberi kesempatan lapangan pekerjaan bagi masyarakat lokal sehingga akan meningkatkan kesejahteraan masyarakat [2]. Kekhasan yang dimiliki oleh industri kreatif yang sarat akan pengalaman dan nilai-nilai sejarah memberi kesan tersendiri bagi wisatawan yang akan mendukung pengembangan pariwisata lokal [3].

Kota Mojokerto merupakan kota yang memiliki potensi industri pengolahan, seperti industri kulit, barang dari kulit, alas kaki, dan miniatur kapal. Pertumbuhan ekonomi Kota Mojokerto di sektor industri pengolahan pada tahun 2017 mencapai $6,2 \%$ dan terjadi peningkatan pesat pada tahun 2018 sebesar 734.543,3 juta rupiah, tahun 2017 sebesar 669.352 juta rupiah, tahun 2016 sebesar 607.057,6 juta rupiah, tahun 2015 sebesar 549.758 juta rupiah. Minimnya sumber daya alam (SDA) yang dapat dimanfaatkan menjadi destinasi pariwisata menjadikan hal tersebut embrio/ potensi yang mendorong pengembangan kawasan wisata industri kreatif untuk menjadi salah satu penggerak destinasi pariwisata di Kota Mojokerto. Wisatawan dapat menikmati dan berpartisipasi dalam proses produksi menghasilkan suatu barang produk kreatif.

Menurut DCMS (Creative Digital Industries National Mapping Project ARC Centre of Excellent for Creative Industries and Innovation) (2007) bahwa industri kreatif adalah industri yang berasal dari pemanfaatan kreativitas, ketrampilan, serta bakat individu untuk menciptakan kesejahteraan serta lapangan kerja melalui pemanfaatan daya kreasi dan daya cipta setiap individu tersebut [5]. Klasifikasi jenis industri kreatif berdasarkan [6] meliputi (1) Periklanan, (2) Arsitektur, (3) Pasar barang seni, (4) Kerajinan, (5) Desain, (6) Fesyen, (7) Video, film, dan fotografi, (8) Permainan interaktif, (9) Musik, (10) Seni pertunjukan, (11) Penerbitan dan percetakan, (12) Layanan komputer dan piranti lunak, (13) Televisi dan radio, dan (14) 


\section{Riset dan pengembangan.}

Guna mendorong terciptanya sektor industri kreatif yang produktif diperlukan optimalisasi pada aspek-aspek yang mendorong perkembangan industri kreatif. Beberapa literatur menyebutkan aspek-aspek pendorong perkembangan industri kreatif meliputi (1) Sumber Daya Manusia (SDM), dimana berperan dalam memberikan ide, gagasan, dan solusi untuk mengatasi permasalahan dalam pengembangan pariwisata berbasis kreativitas; (2) Modal, sebagai dasar membangun usaha; (3) Teknologi, dapat mempengaruhi jumlah produktivitas barang maupun jasa; (4) Kebijakan, berfungsi dalam mengatur keberlanjutan industri kreatif juga diperlukan baik dari sisi internal (perusahaan) terkait maupun kebijakan eskternal (Pemerintah dan Pemerintah Daerah); (5) Partisipasi lembaga dan komunitas lokal, sebagai subjek dan objek pembangunan; (6) Inovasi produk, produk inovasi baru berasal dari segi desain, bahan baku, alat atau pemanfaatanan limbah; dan (7) Kualitas produk.

Sektor pariwisata berbasis kreativitas dianggap merupakan salah satu penggerak utama ekonomi kreatif di seluruh dunia, dimana wisatawan adalah konsumen utama barang dan jasa kreatif. Kawasan wisata kreatif merupakan kawasan yang memiliki keunikan ekonomi kreatif dan daya kreatif masyarakat lokal dalam mengembangkan kawasannya sebagai modal utama sekaligus aset dalam menjadikan kawasan sebagai kawasan wisata industri kreatif. Lebih lanjut, wisata kreatif bukan hanya terkait dengan diversifikasi produk industri namun juga terkait kegiatan atau upaya pelestarian nilai-nilai lokal karena memiliki keunikan [3]. Kreativitas memiliki beberapa tipologi yang didasarkan pada aktivitas/ kegiatannya, yaitu: (1) Berbasis budaya kehidupan masyarakat, (2) Berbasis teknologi, (3) Berbasis pengetahuan, (4) Berbasis olahraga, dan (5) Berbasis seni. Aspek pendorong pariwisata berbasis kreativitas juga dipengaruhi oleh beberapa hal meliputi: (1) Keberadaan industri kreatif dalam kawasan, (2) Wisatawan kreatif, (3) Atraksi wisata kreatif, (4) Fasilitas pendukung wisata, dan (5) Adanya partisipasi masyarakat [3].

Pengembangan sektor pariwisata berbasis kreativitas dikuatkan dengan teori yang menyatakan bahwa syarat suatu objek baik tempat maupun kegiatan dapat dijadikan tujuan wisata kreatif, yaitu (1) "something to see" dapat dikaitkan dengan menikmati proses pembuatan produk industri kreatif, (2) "something to do" dapat dikaitkan dengan aktivitas wisata untuk belajar mengenai proses pembuatan dan (3) "something to buy" terkait dengan membeli produk.

Pendekatan wisata industri digunakan dalam penelitian karena Kota Mojokerto memiliki potensi produk lokal terkait industri kreatif yang beragam dan sudah memiliki jangkauan pemasaran baik lokal, nasional, dan internasional. Potensi industri kreatif, seperti alas kaki, miniatur kapal, kuliner khas daerah dan batik dapat menjadi modal dasar pengembangan kawasan sebagai kawasan wisata berbasis industri kreatif. Pengembangan sektor industri kreatif dapat dijadikan sebagai penggerak baru destinasi wisata di Kota Mojokerto. Berdasarkan latar belakang tersebut, penelitian bertujuan untuk merumuskan strategi pengembangan kawasan wisata berbasis industri kreatif di Kota Mojokerto.

\section{METODE PENELITIAN}

\section{A. Jenis dan Pendekatan Penelitian}

Jenis penelitian yang digunakan adalah penelitian kualitatif. Penelitian kualitatif bertujuan untuk menjawab permasalahan yang memerlukan pemahaman secara mendalam dalam konteks waktu dan situasi yang bersangkutan secara deskriptif. Penelitian kualitatif dipilih karena penelitian bertujuan untuk merumuskan strategistrategi pengembangan kawasan wisata industri kreatif menggunakan pendekatan rasionalistik, berdasarkan fakta dan fenomena yang ditemukan di lapangan.

\section{B. Lokasi Penelitian}

Penelitian dilakukan di Kota Mojokerto. Gambar 1 menunjukkan peta administrasi Kota Mojokerto. Kota Mojokerto memiliki batas wilayah sebagai berikut:

Utara : Sungai Brantas

Selatan: Kecamatan Sooko, Kabupaten Mojokerto

Barat : Kecamatan Sooko, Kabupaten Mojokerto

Timur : Kecamatan Mojoanyar, Kabupaten Mojokerto

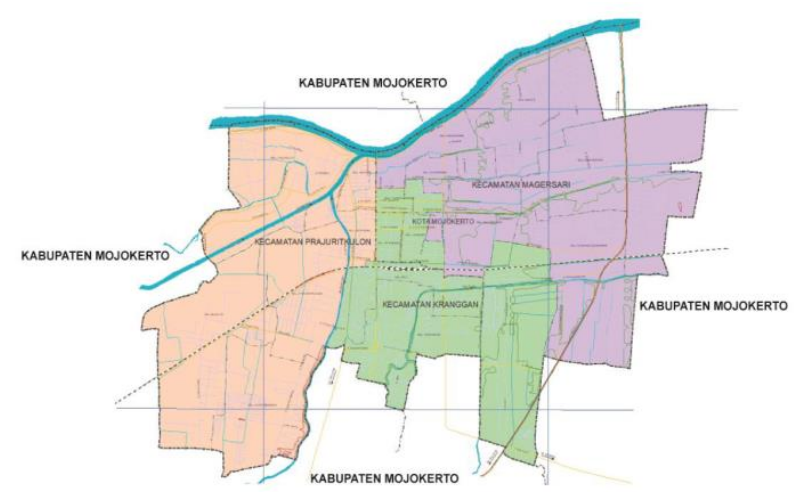

Gambar 1. Peta Administrasi Kota Mojokerto

Sumber: [4]

\section{Teknik Pengumpulan Data}

Pengumpulan data dilakukan dengan menggunakan metode pengumpulan data primer dan sekunder. Metode pengumpulan data primer dilakukan dengan observasi lapangan dan wawancara kepada pihak-pihak yang terkait dengan pengembangan wisata industri kreatif di Kota Mojokerto, yaitu Badan Perencanaan Pembangunan (Bappeko) Kota Mojokerto, Dinas Pemuda, Olahraga, Kebudayaan, dan Pariwisata Kota Mojokerto, Dinas Perindustrian dan Perdagangan Kota Mojokerto dan Perangkat Kecamatan di Kota Mojokerto, meliputi Kecamatan Magersari, Kranggan, dan Prajuritkulon. Wawancara dilakukan dengan metode purposive sampling. Observasi langsung dilakukan untuk mengamati sarana, prasarana, serta aktivitas kawasan pada kawasan wisata industri kreatif.

Sementara itu, metode pengumpulan data sekunder dilakukan dengan survei instansional dan survei literatur. Survei instansional merupakan survei terhadap objek instansi atau dinas terkait yang berhubungan dengan pengembangan wisata industri kreatif. Sedangkan survei literatur merupakan survei terhadap pustaka atau literatur terkait teori ataupun kebijakan terkait konsep pengembangan wisata industri kreatif.

\section{Teknik Analisis Data}

Penelitian menggunakan teknik analisis SWOT dengan pendekatan kualitatif matriks SWOT menampilkan delapan kotak yaitu dua paling atas adalah kotak faktor eksternal (peluang dan ancaman) sedangkan dua kotak sebelah kiri 
adalah faktor internal (kekuatan dan kelemahan) [4][7]. Tabel 1 menunjukkan model Matriks SWOT Kearns:

Tabel 1.

Matriks SWOT Kearns

\begin{tabular}{lcc}
\hline \hline Internal Eksternal & $\begin{array}{c}\text { Peluang } \\
\text { (Opportunities) }\end{array}$ & $\begin{array}{c}\text { Ancaman } \\
\text { (Threats) }\end{array}$ \\
\hline Kekuatan (Strengths) & $\begin{array}{l}\text { Comparative } \\
\text { Advantange } \\
\text { Divestment/ } \\
\text { Kelemahan (Weakness) }\end{array}$ & Mobilization \\
\hline \hline
\end{tabular}

Sumber: Kearns (dalam [17])

Tahapan penelitian ini diawali dengan mengidentifikasi jenis komoditi unggulan yang ada di Kota Mojokerto berdasarkan pertimbangan telaah dokumen dan hasil wawancara dengan stakeholder. Selanjutnya, tahap kedua adalah merumuskan strategi-strategi pengembangan kawasan wisata industri kreatif di Kota Mojokerto menggunakan teknik analisis SWOT.

\section{HASIL DAN DISKUSI}

\section{A. Karakteristik Wisata di Kota Mojokerto}

Jenis wisata yang terdapat di Kota Mojokerto dilihat pada Gambar 2. Berdasarkan hasil observasi dan telaah dokumen memperlihatkan bahwa secara garis besar Kota Mojokerto memiliki 8 jenis wisata, antara lain wisata buatan, wisata belanja, wisata kuliner, wisata pendidikan, wisata sejarah, wisata alam, dan wisata budaya. Jumlah objek wisata kuliner merupakan jenis wisata yang paling banyak ditemukan mencapai 243 objek.

\begin{tabular}{|r|l|l|l|}
\hline Wisata Buatan & 1 & & \\
Wisata Belanja & 1 & 243 \\
Wisata Kuliner & & & \\
Wisata Pendidikan & 1 & \\
Wisata Religi & 2 & 2 & \\
Wisata Sejarah & 1 & \\
Wisata Alam & 1 & \\
Wisata Budaya & 1 & \\
\hline
\end{tabular}

Gambar 2. Jumlah ODTW di Kota Mojokerto Tahun 2018

Berdasarkan Gambar 2 dapat dinyatakan bahwa kondisi pariwisata di Kota Mojokerto masih kurang tereksplorasi keberadaan serta keberagaman objek daya tarik wisata. Selain itu, kurangnya eksistensi wisata yang diakibatkan dari minimnya sumber daya alam (SDA) yang dapat dijadikan objek daya tarik wisata.

\section{B. Karakteristik Industri Kreatif di Kota Mojokerto}

Industri kreatif di Kota Mojokerto tersebar di seluruh kecamatan dengan berbagai jenis industri kreatif, seperti fesyen, kuliner, seni kriya, desain interior, dan lain-lain. Secara administratif, sebagian besar jumlah keberadaan lokasi industri kreatif berada di Kecamatan Prajuritkulon dengan total mencapai 633 unit jenis industri kreatif. Dominasi jenis industri kreatif di Kota Mojokerto meliputi jenis industri kreatif, antara lain: (1) fesyen, yaitu adanya komoditi seperti sepatu, sandal, sepatu/sandal, dan batik sebanyak 703 jenis (2) kuliner, yaitu adanya komoditi seperti kue basah, kue kering, dan keripik khas buatan warga lokal Kota Mojokerto sebanyak 660 jenis (3) kriya, yaitu adanya komoditi seperti miniatur kapal, cetakan kue cor aluminium, dan souvenir. Tabel 2 menunjukkan jenis dan jumlah industri di Kota Mojokerto tahun 2019.

Tabel 2.

Jenis dan Jumlah Industri di Kota Mojokerto Tahun 2019

\begin{tabular}{lcccc}
\hline \multicolumn{1}{c}{$\begin{array}{c}\text { Jenis } \\
\text { Industri }\end{array}$} & Kranggan & Prajuritkulon & Magersari & Jumlah \\
\hline $\begin{array}{l}\text { Desain } \\
\text { Interior }\end{array}$ & 17 & 19 & 34 & $\mathbf{7 0}$ \\
$\begin{array}{l}\text { Desain } \\
\text { Produk }\end{array}$ & 3 & 7 & 8 & $\mathbf{1 8}$ \\
Fashion & 197 & 387 & 119 & 703 \\
Film, & & & & \\
Animasi, & 1 & 0 & 1 & 2 \\
Video & & 0 & 1 & 1 \\
Fotografi & 0 & 45 & 41 & 120 \\
Kriya & 34 & 154 & 290 & 660 \\
Kuliner & 216 & 19 & 19 & $\mathbf{5 8}$ \\
Penerbitan & 20 & 2 & 1 & $\mathbf{3}$ \\
Seni Rupa & 0 & $\mathbf{6 3 3}$ & $\mathbf{5 1 4}$ & \\
Jumlah & $\mathbf{4 8 8}$ & & & \\
\hline \hline Sumber: [4] & & & & \\
\hline
\end{tabular}

Berdasarkan data pada Tabel 2 menunjukkan bahwa Kota Mojokerto memiliki potensi industri terbesar pada industri fesyen, kuliner, dan kriya. Hal ini dapat dilihat dari banyaknya outlet kuliner, fesyen, dan jasa kriya membuat perkembangan pesat di Kota Mojokerto. Sebagai pendukung aktivitas wisata untuk memasarkan produk industri tersebut, Pemerintah Kota Mojokerto membangun Mall Pelayanan Publik terpadu.

Beberapa gambaran mengenai potensi lokal Kota Mojokerto terlihat di Gambar 3. Gambar 3 memperlihatkan bahwa potensi unggulan di tiap kecamatan di Kota Mojokerto dijadikan landmark di masing-masing kecamatan. Adanya landmark dengan desain potensi lokal pada setiap kecamatan berfungsi sebagai identitas kawasan kecamatan, penguatan citra kawasan (ikonisasi), dan orientasi diri bagi wisatawan.

Kecamatan Prajuritkulon memiliki landmark kawasan berupa patung sepatu atau alas kaki (lihat gambar 3a). Hal ini menunjukkan bahwa Kecamatan Prajuritkulon memiliki identitas kawasan yang kuat dengan produk unggulan kawasan industri kreatif alas kaki dan sudah terbentuk branding kawasan industri kreatifnya.

Kecamatan Kranggan yang terletak pada center Kota Mojokerto memiliki landmark berupa miniatur kapal (lihat gambar 3b). Miniatur kapal pinisi menjadi kebanggaan masyarakat Kota Mojokerto. Proses produksi industri kreatif miniatur kapal tergantung dari pesanan pembeli, jadi tidak diproduksi sewaktu-waktu.

Kecamatan Magersari memiliki landmark kawasan berupa patung kue onde-onde (lihat gambar 3c). Kue ondeonde sudah ditemukan sejak zaman Kerajaan Majapahit di daerah Mojokerto. Onde-onde juga menjadi ikon kuliner Kota Mojokerto sehingga dijadikan sebagai oleh-oleh khas Kota Mojokerto. 


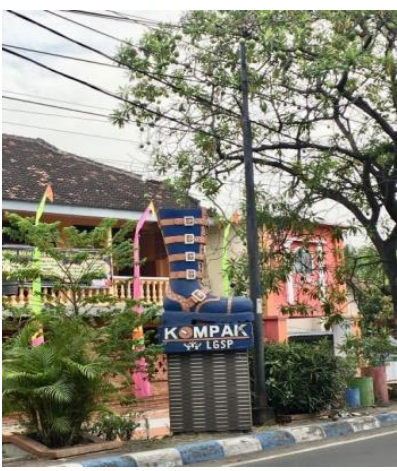

(a)

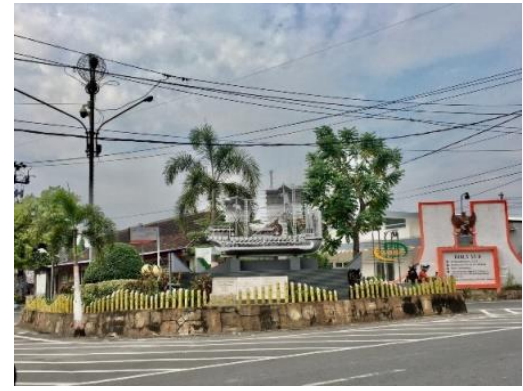

(b)

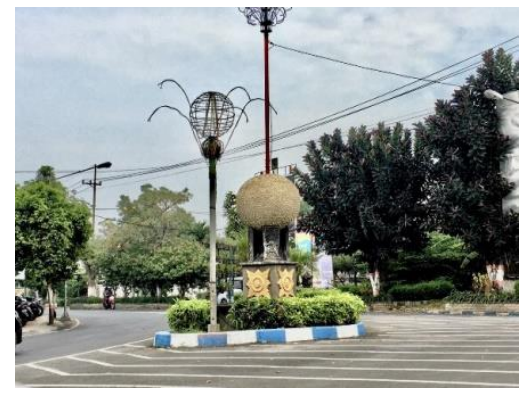

(c)

Gambar 3. Landmark Tiap Kecamatan di Kota Mojokerto (a) Kecamatan Prajuritkulon dengan Landmark Patung Sepatu/ Alas Kaki, (b) Kecamatan Kranggan dengan Landmark Miniatur Kapal, (c) Kecamatan Magersari dengan Landmark Patung Onde-Onde

\section{Pendekatan Konsep Pengembangan}

Pendekatan pengembangan konsep "One Village One Product” (OVOP) yang telah diterapkan diberbagai negara sebagai bentuk solusi peningkatan perkembangan Industri Kecil Menengah (IKM) [9]. Maka dari itu, konsep OVOP menjadi dasar awal pembentukan konsep baru yang lebih adaptif dalam mendukung pengembangan kawasan wisata yang berbasis industri kreatif di Kota Mojokerto.

Konsep yang ditawarkan sebagai strategi pengembangan kawasan wisata industri Kota Mojokerto adalah konsep baru yang dinamakan "One District One Product" (ODOP) jika dalam Bahasa Indonesia berarti "Satu Kecamatan Satu Produk" (lihat Gambar 4). Konsep tersebut dinilai sesuai dengan kondisi dan karakteristik wilayah di Kota Mojokerto sebagai kawasan perkotaan.

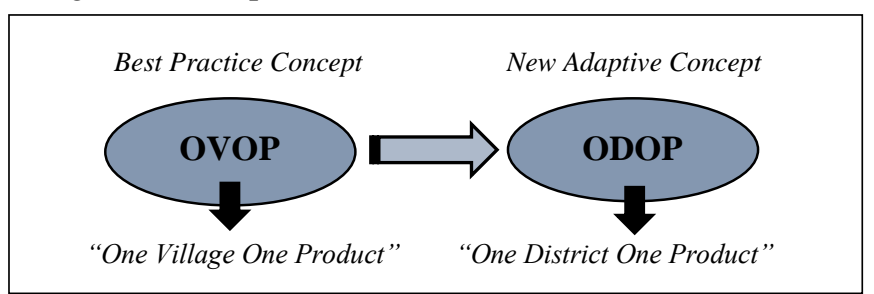

Gambar 4. Konsep Pengembangan Wisata Industri Kreatif Kota Mojokerto
Konsep ini diadopsi dari pendekatan konsep OVOP yang menekankan pada penggunaan sumber daya local, kearifan lokal, dan menghasilkan nilai tambah tinggi [8]. Konsep ini menekankan pada upaya pengembangan produk unggulan lokal yang dianggap memiliki keunikan, kekhasan dan kebermanfaatan yang besar [9]. Produk yang dipilh harus dapat menjadi kompetensi unggulan daerah [4].

\section{Jenis Komoditi Unggulan Setiap Kecamatan}

Kota Mojokerto merupakan kota yang beragam akan industri kreatif. Hal tersebut dapat dijadikan embrio untuk dikawinkan dengan sektor potensial lainnya, yaitu sektor pariwisata. Berikut ini komoditi unggulan yang merupakan produk unggulan daerah dan/ atau produk kompetensi inti daerah serta memiliki keunikan khas budaya dan keaslian lokal kecamatan di Kota Mojokerto dirangkum di Tabel 3. Tabel 3.

Komoditi Unggulan Setiap Kecamatan di Kota Mojokerto

\begin{tabular}{|c|c|c|}
\hline Kecamatan & $\begin{array}{l}\text { Komoditi } \\
\text { Unggulan } \\
\text { Terpilih } \\
\end{array}$ & Keterangan \\
\hline Kranggan & $\begin{array}{c}\text { Miniatur } \\
\text { Kapal }\end{array}$ & $\begin{array}{l}\text { Penetapan komoditi } r \text { unggulan } \\
\text { miniatur kapal di Kecamatan } \\
\text { Kranggan ditetapkan berdasarkan } \\
\text { pendekatan faktor keunikan produk } \\
\text { unggulan serta terdapat } \\
\text { sanggar/rumah produksi kriya } \\
\text { miniatur kapal yang masih eksis } \\
\text { hingga sekarang yang beralamat di } \\
\text { Kecamatan Kranggan. }\end{array}$ \\
\hline Prajuritkulon & $\begin{array}{c}\text { Alas Kaki } \\
\text { (Sepatu dan } \\
\text { Sandal) }\end{array}$ & $\begin{array}{l}\text { Penetapan komoditi unggulan alas } \\
\text { kaki di Kecamatan Prajuritkulon } \\
\text { ditetapkan berdasarkan pendekatan } \\
\text { faktor dominasi jumlah kegiatan } \\
\text { komoditi industri kreatif yang } \\
\text { berlangsung di Kecamatan } \\
\text { Prajuritkulon sehingga sebagian } \\
\text { kawasan menjadi julukan "kampung } \\
\text { sepatu". }\end{array}$ \\
\hline Magersari & $\begin{array}{c}\text { Kuliner } \\
\text { (Onde-onde } \\
\text { dan macam- } \\
\text { macam } \\
\text { Keripik) }\end{array}$ & $\begin{array}{l}\text { Penetapan komoditi unggulan } \\
\text { kuliner di Kecamatan Magersari } \\
\text { ditetapkan berdasarkan pendekatan } \\
\text { faktor keunikan (kekhasan) produk } \\
\text { unggulan serta terdapat pusat oleh- } \\
\text { oleh makanan khas Kota Mojokerto. }\end{array}$ \\
\hline
\end{tabular}

\section{E. Isu Strategis}

Berdasarkan hasil kajian dokumen RTRW Kota Mojokerto Tahun 2012-2032 dan Rencana strategis proyek Kementerian Perindustrian Republik Indonesia Tahun 2016 terkait pengembangan kawasan wisata industri kreatif di Kota Mojokerto, Tabel 4 memperlihatkan isu-isu strategis di Kota Mojokerto terkait dengan wisata industri kreatif.

Tabel 4.

Isu Strategis di Kota Mojokerto

\begin{tabular}{lll}
\hline \hline No. & \multicolumn{1}{c}{ Isu Industri Kreatif } & \multicolumn{1}{c}{ Isu Kepariwisataan } \\
\hline 1. & $\begin{array}{l}\text { Letak Kota Mojokerto yang } \\
\text { strategis untuk distribusi hasil } \\
\text { produksi industri kreatif } \\
\text { Industri kreatif berupa alas } \\
\text { kaki Kota Mojokerto } \\
\text { ditetapkan sebagai kompetensi } \\
\text { inti daerah oleh Pemerintah }\end{array}$ & $\begin{array}{l}\text { Pengembangan wisata bukan } \\
\text { merupakan tujuan utama } \\
\text { pembangunan Kota Mojokerto }\end{array}$ \\
$\begin{array}{l}\text { Kota Mojokerto dan menjadi } \\
\text { proyek pengembangan IKM } \\
\text { Kementerian Perindustrian } \\
\text { Republik Indonesia }\end{array}$ & $\begin{array}{l}\text { Potensi pariwisata yang sudah } \\
\text { segi pemanfaatan, pengelolaan } \\
\text { maupun nilai jual kepada } \\
\text { masyarakat }\end{array}$ \\
\hline \hline
\end{tabular}




\begin{tabular}{lll}
\hline \hline No. & \multicolumn{1}{c}{ Isu Industri Kreatif } & \multicolumn{1}{c}{ Isu Kepariwisataan } \\
\hline & Pendirian pusat informasi/ & Pengembangan perdagangan \\
dan jasa diarahkan untuk \\
3. & promosi (atau pusat grosir/ & mendukung konsep kegiatan \\
& outlet) alas kaki Kota & pariwisata Kota Mojokerto \\
& Mojokerto & sebagai wisata belanja dan \\
& & kuliner \\
\hline \hline
\end{tabular}

F. Perumusan Strategi Pengembangan Kawasan Wisata Industri Kreatif di Kota Mojokerto

Berdasarkan gambaran umum karakteristik pariwisata dan industri kreatif di Kota Mojokerto, kajian pendekatan konsep pengembangan ODOP, serta isu strategis yang sedang berkembang, dapat dirumuskan kelebihan, kekurangan, potensi, dan ancaman yang dijabarkan di Tabel 5 (Analisis SWOT Internal) dan Tabel 6 (Analisis SWOT Eksternal).

Teknik analisis SWOT adalah teknik analisis yang digunakan untuk membantu merancang strategi dan program-program pembangunan [10]. Teknik analisis SWOT digunakan untuk merumuskan program dan strategi pengembangan Kota Mojokerto kaitannya pengembangan kawasan wisata industri kreatif yang di dalamnya memuat identifikasi terhadap potensi, masalah, kekuatan dan peluang yang perlu dielaborasi untuk dapat dioptimalkan.

Tabel 5.

Analisis SWOT Internal

\begin{tabular}{|c|c|}
\hline Kode & Kekuatan (Strengths) \\
\hline S1 & Keberagaman jenis industri kreatif \\
\hline $\mathbf{S 2}$ & $\begin{array}{l}\text { Produk unggulan setiap kecamatan mempunyai ciri khas } \\
\text { (otentitsitas) produk }\end{array}$ \\
\hline S3 & $\begin{array}{l}\text { Salah satu produk unggulan kecamatan telah mencapai pasar } \\
\text { internasional }\end{array}$ \\
\hline Kode & Kelemahan (Weakness) \\
\hline W1 & Pelaku industri kreatif belum memiliki komitmen bersama \\
\hline W2 & Tidak ada standart yang mengatur kualitas produk \\
\hline W3 & Belum adanya ODTW yang berbasis industri kreatif \\
\hline W4 & Partisipasi masyarakat rendah \\
\hline W5 & Rendahnya tingkat pendidikan dan ketrampilan tenga kerja \\
\hline W6 & Kurangnya inovasi produk (kreativitas) \\
\hline W7 & Belum mengoptimalkan pemanfaatan teknologi \\
\hline W8 & Belum adanya ruang pamer produk (workshop) \\
\hline W9 & Kurang optimal fungsi bangunan bengkel kerja \\
\hline W10 & Rendahnya peran kelembagaan \\
\hline W11 & Kegiatan produksi yang masih musiman (tidak kontinyu) \\
\hline
\end{tabular}

Tabel 6.

Analisis SWOT Eksternal

\begin{tabular}{|c|c|}
\hline Kode & Peluang (Opportunities) \\
\hline 01 & Objek daya tarik wisata (ODTW) baru \\
\hline $\mathbf{O 2}$ & Peningkatan pendapatan daerah \\
\hline $\mathbf{O 3}$ & Peluang investasi \\
\hline 04 & Peningkatan produktivitas dan kreativitas masyarakat \\
\hline $\mathbf{0 5}$ & $\begin{array}{l}\text { Ekonomi kreatif sebagai penyangga mendukung menuju } \\
\text { Kota Mojokerto Bahari }\end{array}$ \\
\hline O6 & $\begin{array}{l}\text { Membantu menyerap tenaga kerja untuk mengurangi } \\
\text { pengangguran }\end{array}$ \\
\hline
\end{tabular}

\begin{tabular}{cl}
\hline Kode & \multicolumn{1}{c}{ Ancaman (Threats) } \\
\hline T1 & $\begin{array}{l}\text { Perlaku kompetitif pesaing pelaku industri kreatif dengan } \\
\text { cara memainkan harga untuk mendapatkan konsumen } \\
\text { Belum ada kebijakan khusus/ rencana yang mengamanatkan } \\
\text { bahwa Kota Mojokerto akan mengembangkan sektor industri } \\
\text { kreatif. }\end{array}$ \\
\hline
\end{tabular}

Berdasarkan hasil sintesis SWOT internal dan eksternal pada Tabel 5 dan Tabel 6, dapat dirumuskan strategi-strategi pengembangan kawasan wisata industri kreatif di Kota Mojokerto sebagaimana di Tabel 7.

Tabel 7.

Rumusan Strategi Pengembangan Kawasan Wisata Industri Kreatif di Kota Mojokerto

\begin{tabular}{|c|c|c|}
\hline & Peluang (Opportunities) & Ancaman (Threats) \\
\hline $\begin{array}{c}\text { Kekuatan } \\
\text { (Strengths) }\end{array}$ & $\begin{array}{l}\text { Mengoptimalkan kekuatan } \\
\text { yang dimiliki, antara lain: } \\
\text { S1, O1, O5,O6: } \\
\text { Mengembangkan } \\
\text { keberadaan industri kreatif } \\
\text { sebagai objek daya tarik } \\
\text { wisata (ODTW) baru di Kota } \\
\text { Mojokerto. } \\
\text { S2, O4: } \\
\text { Meningkatkan daya saing } \\
\text { produk unggulan melalui } \\
\text { standarisasi produk. } \\
\text { S2, S3, O4, O5: } \\
\text { Mengembangkan inovasi } \\
\text { produk industri } \\
\text { kreatif } \\
\text { S3, O2,O3: } \\
\text { Menciptakan sistem } \\
\text { pemasaran modern } \\
\text { (e-commerce) } \\
\text { untuk memperluas sasaran } \\
\text { dan segmentasi pasar. } \\
\text { S2, O1, O4: } \\
\text { Mendirikan ruang } \\
\text { workshop } \\
\text { sebagai ruang } \\
\text { pamer produk untuk } \\
\text { menarik minat wisatawan } \\
\text { S2, O4, O6: } \\
\text { Memperkuat peran } \\
\text { kelembagaan di setiap }\end{array}$ & $\begin{array}{l}\text { S1, S2, T1: } \\
\text { Pengendalian harga } \\
\text { yang tidak sesuai } \\
\text { harga pasar pada } \\
\text { produk dapat } \\
\text { dilakukan melalui } \\
\text { temu usaha dengan } \\
\text { membentuk } \\
\text { komitmen } \\
\text { (kesepakatan) } \\
\text { kerja bersama. } \\
\text { S2, T2: } \\
\text { Penguatan } \\
\text { kelembagaan yaitu } \\
\text { peran pemerintah, } \\
\text { swasta/ komunitas } \\
\text { dan masyarakat } \\
\text { dalam meningkatkan } \\
\text { usaha promosi, jasa } \\
\text { pelayanan, dan } \\
\text { penyediaan } \\
\text { infrastruktur } \\
\text { pendukung wisata } \\
\text { S1, S2, T1: } \\
\text { mengembangkan } \\
\text { kawasan budidaya } \\
\text { dengan } \\
\text { memperhatikan daya } \\
\text { dukung dan daya } \\
\text { tampung lingkungan } \\
\text { serta mitigasi } \\
\text { bencana }\end{array}$ \\
\hline
\end{tabular}

kecamatan dalam rangka mengembangkan produk unggulan yang berkelanjutan.

\begin{tabular}{cll}
\hline & W3, W6, O1, O5: & W3, W8, T2: \\
& Memperkuat identitias & Pemerintah daerah \\
& ODTW berbasis industri & merancang \\
& kreatif sebagai destinasi & Masterplan \\
& wisata di Kota Mojokerto & Kawasan Wisata \\
& W4, W5, O4, O6: & Industri Kreatif agar \\
& Melibatkan peran aktif & pengembangan \\
& masyarakat setempat sebagai & terarah dan \\
& tenaga kerja lokal untuk & berkelanjutan \\
& mengurangi pengganguran. & W1, W2, T1: \\
& W4, W5, W10, O4: & Adanya kebijakan \\
Menjalin kerjasama yang & mengenai standart \\
(Weakness & sinergis antar stakeholder & produk guna sebagai \\
& (Pemerintah, swasta, dan & menjaga kualitas \\
& masyarakat). & produk unggulan \\
& W6, W7, W11, O2, O3, O4: & W8, W9, T2: \\
& Modal dari investor untuk & Memperketat \\
& meningkatkan kualitas dan & peraturan zonasi \\
& perluasan pemasaran produk & kawasan sebagai \\
industri kreatif & bentuk pengendalian \\
W1, W5, O4, O6: & kawasan \\
& Mengadakan pemberdayaan & \\
masyarakat melalui pelatihan & \\
dan bantuan modal & \\
\hline \hline
\end{tabular}




\begin{tabular}{ll}
\hline \hline Peluang (Opportunities) & Ancaman (Threats) \\
\hline pengembangan usaha & \\
W9, O4: & \\
Menghidupkan kembali & \\
fungsi bangunan bengkel & \\
kerja. & \\
\hline \hline
\end{tabular}

Berdasarkan hasil rumusan strategi SWOT pada Tabel 7, dapat dikerucutkan beberapa strategi pengembangan industri wisata kreatif di Kota Mojokerto:

\section{1) Strategi Keruangan}

Berdasarkan hasil analisis SWOT didapatkan bahwa Kota Mojokerto memiliki diversifikasi jenis industri kreatif dan berpeluang untuk dikembangkan menjadi destinasi wisata, mengingat minimnya jumlah Objek Daya Tarik Wisata (ODTW) yang ada di Kota Mojokerto. Dikaitkan dengan pendekatan konsep ODOP bahwa setiap kecamatan telah memiliki produk unggulan dan memiliki nilai keunikan/ kekhasan dan kearifan lokal serta nilai sejarah dari aspek bahan baku dan/ atau ketrampilan maupun budaya lokal dan memiliki tata ruang yang jelas. Untuk itu, strategi keruangan yang dirumuskan adalah pembagian ruang kawasan sebagai ODTW yang berbasis industri kreatif dengan memperhatikan keunikan/ kekhasan masing-masing kecamatan dan memperkuat citra keruangan yang sudah ada dan mendirikan ruang workshop/ pusat grosir/ pusat oleholeh sebagai ruang pamer produk industri kreatif yang dihasilkan serta menjadi motivasi pengunjung dalam melakukan perjalanan wisata di Kota Mojokerto.

\section{2) Strategi Nonspasial}

Berdasarkan hasil analisis SWOT, Kota Mojokerto memiliki produk unggulan setiap kecamatan yang unik dan otentik. Namun mengalami permasalahan pada kegiatan produksi masih kurang konsisten dan kontiyu, perilaku kompetitif pesaing pelaku industri kreatif dengan persaingan harga untuk mendapatkan konsumen, dan belum ada standar yang mengatur kualitas produk. Selain itu, jika direlevankan dengan Rencana Strategis Kementerian Perindustrian RI untuk Kota Mojokerto tahun 2016, industri kreatif komoditi alas kaki telah ditetapkan menjadi proyek nasional dalam pengembangan IKM Kementerian Perindustrian RI. Sebagai perumusan strategi pengembangan, pendekatan konsep ODOP digunakan untuk mengadopsi ketentuan bahwa produk unggulan merupakan produk kompetensi inti daerah dan memiliki keunikan tersendiri sebagai nilai jual produk serta dapat diproduksi secara kontiyu dan konsisten dan mampu berkompetisi di pasar domestik dan ekspor. Strategi yang dirumuskan antara lain penguatan sistem produksi dan peningkatan kualitas produk yang berasal dari hasil inovasi dan kreativitas pengembangan produk.

\section{KESIMPULAN/RINGKASAN}

Potensi komoditi unggulan industri kreatif setiap kecamatan di Kota Mojokerto menjadi peluang yang dapat dimanfaatkan sebagai pendorong sektor yang lainnya, yaitu sektor pariwisata. Seperti temuan [2] bahwa berbagai produk industri kreatif memiliki keunikan yang mampu mendorong dan mengembangkan citra kota dan menjadi daya tarik wisata. Hal ini dapat diciptakan dengan memberi landmark kawasan atau ruang-ruang wisata yang dapat dinikmati wisatawan [5]. Pengembangan kawasan yang disesuaikan dengan kondisi kawasan perkotaan menjadikan pendekatan konsep One District One Product (ODOP) dinilai lebih adaptif dengan karakteristik wilayah Kota Mojokerto. Berdasarkan hasil dari analisis SWOT dan isu strategis yang sedang berkembang telah menghasilkan rumusan strategi-strategi pengembangan kawasan wisata industri kreatif di Kota Mojokerto yang dibagi menjadi dua, yaitu (1) strategi pengembangan spasial meliputi pengembangan ODTW baru berbasis industri kreatif, mendirikan ruang workshop, menghidupkan kembali fungsi bengkel kerja, dan mengatur peraturan zonasi sebagai bentuk pengendalian kawasan dan (2) strategi pengembangan nonspasial, meliputi mengembangkan inovasi produk, menciptakan sistem pemasaran modern $(e-$ commerce), memperkuat kelembagaan, meningkatkan peran aktif masyarakat, merancang masterplan kawasan wisata industri kreatif, dan adanya kebijakan standart produk untuk menjaga kualitas produk industri kreatif. Perlu penguatan konektivitas antara industri kreatif dan pariwisata agar mampu memberi nilai tambah ekonomi bagi suatu wilayah yang dapat ditempuh dengan penguatan kapasitas kelembagaan dan sumber daya manusia, perluasan akses pasar, dan sinergisitas peran berbagai stakeholder [6]. Dalam peningkatan kapasitas untuk lebih kreatif perlu peran dari pemangku kepentingan terkait, seperti pemerintah, pelaku usaha, dan akademisi untuk memberikan pelatihan serta pembinaan. Dengan adanya strategi pengembangan tersebut dapat preskripsi dalam mewujudkan pembangunan Kota Mojokerto yang lebih efisien, produktif, dan berkelanjutan.

\section{DAFTAR PUSTAKA}

[1] Nurchayati dan Andalan T R, "Strategi Pengembangan Industri Kreatif sebagai Penggerak Destinasi Pariwisata di Kabupaten Semarang," in Prosiding Seminar Nasional Multidisiplin Ilmu \& Call for Papers Unisbank (SENDI_U) Ke-2 Tahun 2016, 810-819.

[2] P Diana, I K Suwena, dan N M S Wijaya, "Peran dan Pengembangan Industri Kreatif dalam Mendukung Pariwisata di Desa Mas dan Desa Peliatan, Ubud," Jurnal Analisis Pariwisata, Vol. 17, No. 2, (2017) 84-92.

[3] M Damayanti dan L Latifah, "Strategi Kota Pekalongan dalam Pengembangan Wisata Kreatif Berbasis Industri Batik," Jurnal Pengembangan Kota, Vol. 3, No. 2 (Desember 2015) 100-111.

[4] I. G. B. R. Utama. (2016, Jan). Analisis SWOT Deskriptif Kualitatif untuk Pariwisata [Online]. Available: https://www.researchgate.net/publication/289658938_Analisis_SWO T.

[5] S Ratih, E Darmawan, dan D Shamara, "Konsep Pengembangan Ruang Wisata Berbasis Industri Kreatif," Modul, Vol. 16, No. 1, (Januari-Juni 2016) 43-48.

[6] Riswan, Hartiningsih, S Fitriyanti, A Z Maulana, Y Putyanda, T F Puspitasari, dan H A Pradana, "Problematika Pengembangan Ekonomi Kreatif dalam Menunjang Sektor Pariwisata di Kalimantan Selatan," Jurnal Kebijakan Pembangunan, Vol. 13, No. 2, (Desember 2018) 129-139.

[7] M. Mercieca, F. Schembri, A. S. Inglott, and L. M. Azzopardi, "Swot analysis," Pharmaceutical Technology. 2016, doi: 10.4337/9781784712082.00015

[8] A. Wahyudi, "Efektivitas dan Efisiensi Implementasi OVOP dalam Pengembangan IKM Gerabah di Kasongan," J. TATA KELOLA SENI, 2017, doi: 10.24821/jtks.v2i1.1811.

[9] F. R. Schumann, "A Study of One Village One Product (OVOP) and Workforce Development: Lessons for Engaging Rural Communities around the World," J. Int. OVOP Policy, 2016.

[10] E. GÜREL, "SWOT ANALYSIS: A THEORETICAL REVIEW," $J$ Int. Soc. Res., 2017, doi: 10.17719/jisr.2017.1832. 